\title{
Introduction: Islamic Sects and Movements
}

\author{
Carole M. Cusack and M. Afzal Upal
}

Given the presentation of Islam in popular media, it is not surprising that most Westerners (including some scholars) view the faith as a static, monolithic religion that clings fiercely to its seventh century roots, resisting any attempt at change. This is, of course, far from the truth. In common with other faith traditions, Islam has been a dynamic force from the start, with adaptations stemming from individual leaders, diverse ethnic populations, and the cultural contexts in which the religion took root. Christians and Jews, among other representatives of religious traditions, commented on Muhammad, the prophet and founder of Islam, and identified resemblances between the new monotheistic religion and their own traditions (Hoyland 200o). Islamic tradition implicitly recognizes its own diversity; even as some groups label others heretical and denounce the inventions of so-called liar prophets' or fitna ('strife') spread by leaders who have succumbed to ungodly forces, they also acknowledge the relationship between these diverse interpretations and their own creed (van Ess 2001). In this way, Islamic literature tells the story of Musaylimah Kazzab (whose very name contains the word 'liar'), who, along with his followers, was killed by troops sent by Abū Bakr shortly after Muhammad's death (Makin 2010). The Khārijites and Mu'tazilites are also mentioned in standard Sunnī and Shī'a narratives, being portrayed as falling so far outside of mainstream Islam that their ideologies deserve to be wiped out of Islamic thought. Yet, their existence is clearly acknowledged (Timani 2017).

Such innovation in Islamic thought is not restricted to the past. Modern reformers have continued to push the envelope, sometimes being met with comparable disdain from certain Muslim groups as the 'false prophets' of the Prophet Muhammad's time. These reformers include the founders of the Ahmadiyya Muslims Jamā'at (Chapter 27) and the Bahā'ī Faith (Chapter 33). According to traditional Sunnī and Shī'a accounts, such 'heretical' movements have little or no value for scholars interested in understanding 'authentic Islam.' Should scholars of Islam researching the current state of Islam confine themselves, then, to studying only those movements which modern-day mainstream Shī'a and Sunnī Muslims consider to be central to their faith? Do movements that are deemed less than 'fully' Islamic by some Muslims tell us nothing about Islam past, present, or future? The answer for contemporary scholars is clear; Islam is not monolithic, and ideal typical images of the tradition that focus on texts and theology are partial at best, and misleading at worst (Neitz 
2011). The study of lived religion, vernacular religion, and of the diverse Islams that are occasioned by gender, social status, ethnicity, geographical location, and other variables must of necessity enrich scholarly understanding of the Islamic tradition.

Thus, while traditional anthologies, encyclopedias, and handbooks of Islam to date have excluded the 'heretical' movements, related religions (except for Judaism and Christianity), and splinter groups, as well as ignoring political manifestations of the faith, this volume casts a broader net. The goal is to present an overview of the wide variety of religious movements that have their origins in the Islamic world so that scholars and those interested in Islamic history can grasp the full extent of the diverse thought that exists under the name of Islam. We include Sunnī, Shī'a and Șūfi groups, and examinations of movements that were born of the Islamic world but no longer consider themselves part of the Islamic community (for example, Bahā'ī), and movements that consider themselves Islamic but are rejected as such by many Sunnì and Shīa Muslims (such as the Ahmadiyya Muslim Jamā'at).

Perhaps it is inevitable for those who are faithful to slightly differing iterations of a religious tradition to argue about whose beliefs are most valid. Arguably, no other religious quarrels match the longevity and intensity of the Muslim debate over what constitutes the 'true' faith. Who belongs to the 'circle of Islam' (daira-e-Islam) and who is excluded from it? Almost every group has, at one time or another, been accused of being outside the circle of Islam. The heresiographical tradition in Islam appears to date back to its early days. In Chapter 19, Emin Poljarevic gives historical examples of takfir including "ibn Taymiyya's (d. 1328) Mardin fatwā against Syria's Mongol rulers; the Șafavid (Shīīi) Akhbāriyya's takfìr of Muslim philosophers in the 16oos; and most notably, during the 170os, the religious movement of Muhammad ibn 'Abd al-Wahhāb's en masse excommunication of the Sunnī Ottoman and Shīī religious leaders" (Poljarevic 2020). As Najam Haider notes, Muslim heresiographers have often used a hadith which in its most commonly employed variant suggests that 72 out of the 73 sects in Islam are hell-bound: "This framework exercised a decisive influence on heresiographers, who sought to document the proliferation of a predetermined number of sects and positioned their own group as the sole representative of the Prophet's original message. Such a view did not allow for the doctrinal evolution of any single group. A sect was a cohesive and unchanging unit that held a discrete set of doctrines and beliefs" (Haider 2014: 104).

Viewing sects as static and unchanging is clearly unscientific. Sects are groups of individuals who share a set of beliefs. What is commonly referred to as a sect's beliefs are a subset of these beliefs. Many sects start out with 
an individual founder whose ideas evolve and change over time (typically from orthodox to unorthodox). As other individuals join and leave the group, their individually held ideas also change through interactions with each other (Swatos 2007). Thus, a group's shared beliefs dynamically evolve over time. It is this belief change dynamic that makes these groups so fascinating to study. This also means that religious boundaries are more fluid than heresiographers (and even some scholars) have suggested. This includes boundaries between Islamic and non-Islamic movements as well as boundaries between various Islamic sects. Therefore, most of the movements that are considered non-Islamic now started out as strictly Islamic. For instance, founders of Bahā'ī and Ahmadiyya Jamāerat started out holding orthodox Shīa and Sunnī Muslim views. Haider suggests that Zaydism may be an even more interesting case, where a sect's beliefs have oscillated between Shīism and Sunnism (Haider 2014: 105). In order to understand these groups in relation to Islam, we need to understand the evolution of their shared beliefs over time. For those movements that originated in an Islamic milieu, this can be done by analyzing their shared beliefs in comparison with shared beliefs of Muslims in that historical era.

Given the breadth of this volume and the extent of content not conventionally included in collections such as this, questions arise as to the most effective organization of chapters. The first part of the book has seven chapters focusing on non-violent Sunnī movements. The second part contains six chapters on Shī'a and Shīa-related movements. The third part has eight chapters on fundamentalist and extremist movements that are primarily Sunnì in orientation, ranging from the mostly non-violent (for example, Hizb ut-Tahrir) to the violent (culminating in Islamic State). The fourth part covers Șūfi movements and Șüfi-related movements. The fifth part has six chapters describing two different types of movements: first, those that mainstream Muslims do not consider part of Islam, but followers of those movements consider themselves to be Muslims; and second, movements that have historical links to Islam but are separate (for example, Yezidis and Druze).

\section{$1 \quad$ Survey of Contents}

This volume is organized in five sections: Part 1, "Sunnī Traditions"; Part 2, "Shī‘a Traditions"; Part 3, "Fundamentalists and Extremists"; Part 4, "Șūfism and its Influences"; and Part 5, "In Between and On the Fringes of Islam." Three of these sections are uncontroversial; the division of Islam into Sunnī and Shī'a, with Sunfis forming a third grouping that crosses this sectarian divide, is traditional 
(Husain 2018). The other two sections, however, may be less popular, although for different reasons. Fundamentalist instantiations of Islam undeniably exist; yet they are slippery and difficult to define, and it may be objected that there are significant differences between the movements in this section that vitiate any desire to strategically group them together. The final section is likely to be more controversial; of the seven movements covered, only two have a strong 'Islamic' identity (Ahmadiyya and the Nation of Islam), and both are regarded as 'deviant'. The other five are not 'Islamic' sects, in the sense of unorthodox or theological offshoots, but are separate religious entities, both traditional and modern. A distinguishing feature of these groups is that they all have interacted historically, culturally and socially with Islam and have (to some extent) shaped their identities accordingly.

Part 1 introduces the Sunni tradition, beginning with a general overview and progressing through five specific institutions that are associated with different modern nation-states. The section concludes with an overview chapter on women in (Sunnī) Islam. One of the issues facing scholars of Islam relates to the terminology available for characterizing the diversity within Islamic beliefs and behaviors (Sedgwick 200o). Should terms developed originally for the study of Christian movements, 'sect', for instance, be applied to Islamic subdivisions or movements? (Swatos 2007). Ron Geaves examines this question in the first chapter, "Sectarianism in Sunnī Islam." He traces the history of various schisms in Islam, starting from the first century of Islam and the beliefs of early movements (such as the Khārijites), before moving forward to consider modern Sunnī movements (for example, Tablīghī Jamā'at, Jamaat-e-Islami, and the Muslim Brotherhood). Geaves' conclusion identifies political and theological causes for the divisions that remain present in Sunnī Islam.

In Chapter 2, Zacharias Pieri reviews the history of the Tablīghī Jamāat from its origins in the nineteenth century India to the present. He describes a movement dedicated to reviving and strengthening the faith of the existing faithful by making Islam a part of every single aspects of life. Yet, the movement has splintered in recent years with at least two leaders vying for the top spot: Saad ul-Hasan and Zuhairul Hasan. Pieri also reports that the Pakistani and Bangladeshi branches also appear to be moving away from the Indian center and "becoming increasingly powerful due to the large annual congregations held there and the ambitions of the leaders in those regions to have more say in TJ'S global operations. Violent clashes ensued between those loyal to the Indian branch of the movement and those who wanted an expanded leadership" (Pieri 2020). The appeal of Tablīghī Jamācat in varied cultural contexts, including the West, is also examined. 
Sunnī conservatism perhaps best represents the monolithic interpretation of Islam made by many in the contemporary world. As such, Rickard Lagervall's chapter on "The Muslim Brotherhood" and its history, from its origins in early twentieth century Egypt, to the proliferation of offshoots throughout the broader Middle East and North Africa, is enlightening (Chapter 3). Lagervall examines the Brotherhood's founder, Hasan al-Bannā (1906-1949) and the contribution of his contemporary, Sayyid Quṭb (19o6-1966). The Brotherhood's intervention in Egyptian politics is covered, and the tensions between Saudi Wahhābism and the Muslim Brotherhood are analysed. It even becomes evident that offshoots of the Muslim Brotherhood were, in fact, active on both sides of the Algerian Civil War that followed the suspension of the parliamentary election by the military in 1992 (Willis 2012).

The Gülen Movement and the Justice and Development Party (AKP) of Turkey are another case in point. The two movements appear to be similar; for example, both advocated a Sunnī political Islamic revival to remake the Kemalist secular Turkey into a modern Islamic welfare state. In Chapter 4 Caroline Tee surveys the relationship between these two movements, noting they were close allies during the 199os, but had a falling out as the AKP won elections and consolidated its power. Thus, while in the 2002 election, Fethullah Gülen asked his supporters to vote for Recep Tayyip Erdoğan's AKP (leading the AKP to its first majority government), tensions arose between the two allies in the AKP's second term in office over issues such as Turkey's relationship with Israel and how to respond to anti-government protests. The coup of 15 July 2016 seemed to obviate any hope of reconciliation between the two movements. Erdoğan blamed Gülen for orchestrating the coup and ordered arrests of thousands of Gülenists, the dissolution of Gülenist schools, and confiscation of the movement's property.

Chapter 5, Hisanori Kato's "The Islam Nusantara Movement in Indonesia," illustrates the difficulties associated with the traditional approach to studying Islamic movements which insists on drawing clear boundaries. Kato argues that while there are minor differences between the two "modernist" Sunnī movements based in Indonesia, namely, Islam Nusantara and Islam Berkumajuan (such as Nusantara has a more advanced online presence), it is difficult to find genuine theological differences between them. However, these similarities far from making them uniform have only bred "mutual hatred since their establishment." Furthermore, he argues that boundaries between Islam Nusantara and liberal (that is, Jaringan Islam Liberal) as well as more conservative "hardline" Islamists are also not as clearly drawn as some assume them to be. Thus, while some Nusantara leaders of argue against including LG BTQ and 
Ahmadiyya members in the fold of Islam, others argue that they should also be considered Muslims.

In Chapter 6, Faried Saenong reviews the origin and history of the Indonesia-based Sunnī movement Nahdlatul Ulama (NU) which, with its estimated 30-9o million members, claims to be one of the largest Muslim organizations in the world. Like many movements across the Muslim world, NU was launched during the Dutch colonial period in 1926 by a group of 'ulamä' who wanted to voice their concerns to the new Saudi king following the Wahhābist revolution in Saudi Arabia and the launch of Wahhābist Muhammadiyah movement in Indonesia in 1912. Unlike similar movements that arose in other parts of the Muslim world (such as Aḥmad Riḍā Khān's Barelwī Movement in South Asia) to defend traditional Șüfi practices, NU is unique in revering all four Sunnī madhhab founders equally. Saenong discusses how NU balances its insistence on a strict adherence to traditional Sunnī worldview with its progressivism on the issue of allowing local cultural practices. This focus on indigenization of Islam led to the launch of the Islam Nusantara movement, the subject of the previous chapter, in 2015.

In Chapter 7, Eva F. Nisa brings Section I to a conclusion with a review of the role of women in Islam. She commences with the origin of Islam focusing on the role of Prophet Muhammad's wives who (known as 'mothers of the believers') are considered the epitome of Muslim women's piety (Nisa 2020). She progresses through history to a discussion of the role of women in a range of modern movements including the Muslim Brotherhood, Tablīghī Jamāat, Nahdlatul Ulama, Muhammadiyah, Jamaat-e-Islami, and Hizb ut-Tahrir. She cautions against making assumptions about Muslim women's roles and emphasizes the dizzying diversity in Muslim women's voices. This is not new; Nisa presents the contrasting the roles played by the Prophet's wives 'Ā'isha, Khadija and Umm Salama. While 'Ā'isha led one of the first inter-Islamic battles and narrated over 1,500 ahadith, the Prophet's other wives seemed to have played little to no public role in the formation of the new faith. Modern Muslims women's voices range from Islamic feminists such as Fatima Mernissi, to ultra conservative Muslim Brotherhood leader Zaynab al-Ghazali, and everything in between. She concludes that "anyone who wants to understand Muslim women and their activism within diverse Islamic and Islamist movements must avoid the inclination to make broad and unqualified generalisations. The wide geographical scope covered in this chapter also reminds us of the diversity within Muslim-majority countries."

Part 2 of the book covers Shī'a movements beginning with an overview chapter (Chapter 8) by Mohammad Fazlhashemi. He argues that the Shīa-Sunnī conflict began as a contest over secular state power soon after the death of the 
Prophet but, over time, has "widened to include theological, legal, philosophical, cultural, social, and not least political controversies." He stresses, however, that the Shì ite are far from forming a homogeneous group; the Twelvers are the majority, but there are Zaydīs, Ismāilites, and a number of other branches. Fazlhashemi notes that "during a short period in the early history of Shía, between 66o-870, a dozen conflicting factions were formed, all of which laid claim to the correct interpretation within Shīa" (Fazlhashemi 2020). Even in modern-day Iran, which is under Shīa theocratic rule, not everyone agrees with Ayatollah Khomeni's notion of vilayat-e-fiqah (the 'guardianship of legal scholars'); in fact, as Fazlhashemi explains, even "[o]ne of the foremost defenders of the doctrine, the Grand Ayatollah Montazeri (1922-2009), turned his back on it in the mid 198os." The chapter indicates that such opposition to Shīa power has led to demands for a democratic electoral system and the separation of religion and government.

Chapter 9 by Najam Haider tells the fascinating story of Zaydism or Fiver Shīism from being a proto-Sunnī group to a Shī'a denomination in its first two centuries. He starts with the traditional narrative of the formation of Zaydis as a merger of two sects: namely the proto-Sunnī Batrīs and proto-Shīa Jarudis. However, he quickly disposes it as a representation of two "theological orientations as opposed to specific discernible groups" (Haider 2020). He argues that Zaydīs in the middle of the eighth century were predominantly Batri and anti-Mu'tazilite while Zaydīs in the ninth century were increasingly Jarudi and pro Mu'tazilite. He devotes the first part of his two-part chapter to studying the sociocultural and political factors that caused this change prominent among them the leadership of Yahyā bin 'Abd Allāh and the move of the Zaydī center of gravity from Iraq to Yemen. It was in Yemen in the eighteenth and nineteenth centuries when the reverse trend towards Sunnī traditionalism among Zaydīs started under the leadership of Muhammad al-Shawkānī, chief judge appointed by a Zaydī Imam. This Sunnīfication process was only accelerated by the overthrow of the imāmate and its replacement by secular government which has oppressed traditional Zaydism for the fear that it would cause Zaydīs to seek revival of a Zaydī imāmate. This environment has sparked both a backlash and a reinterpretation of Zaydī traditions resulting in a broad diversity of voices ranging from Houthi rebels to interpretive efforts that seek legitimacy of modern Yemeni state through traditional Zaydism.

Farhad Daftary reviews the history of the Ismāi $1 \bar{l}$ (Sevener Shìa) movement starting from the split of the Islam into Sunnī and Shīa camps after the death of the Prophet Muhammad, with a particular focus on the history of the Nizari Ismāîlīis in Chapter 10. It was not, however, till the sixth Imam, Ja far al-Ṣādiq, argues Daftary that Shī‘as became a "major religious community with a distinct 
identity" (Daftary 2020). The unity among the Shīite community did not last long. The issue of Saadiq's succession led to one of many splits in the community. The pure Ismāîliyya believed that Ṣādiq's older son Ismāīl had gone into hiding but was still the imām, while the Mubarakiyya took Șādiq's grandson to be their imām. After the death of the grandson, Mubarakiyya further split into two more groups. The history of Ismāîlì movement is replete with dynamism in which $d \bar{a}$ is from various factions compete with each other, with Imami Shīas, and with Sunnīs of various factions to convince people of their truths. As Ismāîlīis are getting pushed out of one region (e.g., North Africa), they establish themselves in another part of the world (Yemen and Central and Southern Asia).

Chapter 11 of this section reviews the history of Dāùdī the Bohra community of Ismā̄î̀ī Shī‘a Muslims. Being a minority, even among Indian Shī‘a Muslims, Jonah Blank describes the considerable efforts that the Bohras have engaged in to maintain their distinctiveness, and to ensure that they are not absorbed into the much large Hindu or Sunnī populations. These include the efforts by the clerical establishment to maintain their control over the laity, adoption of Western technologies especially telecommunication technologies, and Western education. While having a strong leader in the almost infallible $d \bar{a}$ i muttlaq ensures remarkable amount of uniformity in beliefs and practices, it has not kept the community from splintering into subgroups of including Sulaymāni and 'Alawī Bohras. The most recent split over the succession of Syedna Burhanuddin has not resulted in the formation of a new Bohra subgroup, it has raised "the prospect of another community schism" (Blank 2020).

Yvette Talhamy in Chapter 12 describes the origins of two offshoots of Shi'a Islam: the Alevīs and the 'Alawīs (Dressler 2013; Faksh 1984). She explains that, while both groups revere 'Alī and are concentrated in neighboring regions of Syria and Anatolia, there are a number of important differences between them: "While the 'Alawī/Nuṣayrī creed developed in Iraq in the ninth century and is of Arab origin, the Alevi creed was born several centuries later, stemming mainly of Turkoman tribes that settled in Anatolia during the thirteenth century" (Talhamy 2020). She elaborates on the ways in which the two groups' views of 'Alī and Muhammad diverge, as well as pinpointing differences in their festivals, prayers, and practices. The matter of how 'Alawīs and Alevīs are able to shift their identities from Nuṣayrī to Shī'a Islam (and, in the case of the Dede Commission of the Federation of Alevi Communities in Germany, to non-Islamic identities, too) is deftly handled in this informative chapter.

Chapter 13 is David Thurfell's study of the hey'ati movement in Iran. This chapter is focused on charismatic eulogists or maddāhān and the youth movement that has gathered around them in the past two decades. Thurfell's 
fieldwork in Qom resulted in a multi-faceted characterisation of a movement that has broad popular appeal, draws on Iranian folk religiosity, and has developed into a distinctive subculture expressed through lifestyle, ritual and aesthetics. The hey'ati movement is not explicitly political, but Thurfell argues that "eulogists played a pivotal role in the mobilisation of popular support for former president Mahmoud Ahmadinejad" (Thurfjell 2020). In preRevolutionary Iran a major activity of eulogists was the offering of prayers for the king, a practice that was discontinued after the downfall of the Shah, Reza Pahlavi. In contemporary Iran, eulogists are interesting as non-clerical sources of religious authority, and as supporters of conservative Islamic jurisprudence and opponents of reformist clergy.

Part 3, "Fundamentalisms and Extremists," opens with Chapter 14, in which Joas Wagemakers defines Salafis as Muslims "who claim to have made being 'salaf-like' the be-all and end-all of their ideology." Salaf here refers to the first three generations of Muslims (the so-called "pious predecessors"). Wagemakers divides Salafis into three groups: quietists, political Salafis, and jihādist Salafis. While these groups are similar and share a belief in the ideological purity of the citadel of Islam, Wagemakers cautions against the tendency to generalize about them, pointing out that each group does not consider the others "true Salafis" or, indeed, even Muslims. Moreover, as he elucidates, the various Salafi factions are prone to attacking one another verbally. The quietists, who shun modern political discourse (not unlike the Tablīghīs), brand political Salafis Ikhwāniss, borrowing the name of the highly political Muslim Brotherhood (Al-Ikhwān al-Muslimūn); they also label jihādist Salafis takfîris or khawārij because of their views on takfir. On the other hand, jihādist Salafis (and, to a lesser extent, political Salafis) accuse the quietists of being like the Murjia because of their alleged tendency to exclude acts from their definition of faith, thereby overlooking the 'sinful' acts of supposedly apostate rulers (Lav 2012; Wagemakers 2012a). In this way, Salafis often deny each other the very label of 'Salafi', indicating that, despite a common desire to emulate their predecessors, those within the citadel of Salafism are "deeply divided" (Wagemakers 2020).

In Chapter 15, Jon Armajani starts with an overview of Pakistan's role in Afghanistan that intensified with Soviet invasion of Afghanistan in 1979 as millions of Afghan refugees poured across the border. Many of the refugee children received education at Saudi funded madrasas. After the withdrawal of Soviet troops in 1989, the Afghanistan erupted further into chaos with a seemingly endless infighting among the Mujahideen. Warlords fought with each other over all sort of issues including the fight over a boy. It was such a fight among two war lords that so irritated Mullā Omar, an imām of a village mosque in South Eastern Afghanistan, that he took thirty of his madrasa students to 
rescue the boy. Local people saw him as a hero and joined his cause swelling his rag tag army. Aided by the governments of Pakistan and Saudi Arabia, Omar first took over Kandahar region in the South and eventually Kabul in 1996. His Taliban followers elected his amir-al-mu'minin, commander of the faithful. He declared Afghanistan an Islamic Emirate and imposed a strict Islamic rule. The Taliban rule came to an end in 2001 when US supported their opponents in the aftermaths of $9 / 11$ attacks. However, the Taliban, far from giving up the flight have gone back to their guerilla warfare roots and continue their attempt to restore their rule.

Chapter 16 by Shaul Bartal, expands on the links between the Muslim Brotherhood and the Palestinian movement Ḥamās. Bartal connects Ḥamās with the Palestinian national-resistance movement that began during the period of the British mandate. Even though Hamās was officially founded in 1987, Bartal considers its foundation to have been the start of the organization's second phase. This view is similar to the phase-development notions related to Hizb ut-Tahrir, but involves a shorter period for the preparation of society for jihād because, in contrast with Hizb, Hamās does not believe in the necessity of waiting for a khaliffa to declare jihäd. The remainder of the chapter summarizes the political and military developments within the Israeli-Palestinian conflict since 1987, concentrating especially on the role of Hamās.

Chapter 17 shows how Hizb ut-Tahrir, founded in 1953 by a Palestinian scholar named Taqī al-Dīn al-Nabhānī, holds a similar outlook to Tablīghī Jamā'at, focusing on preaching and outreach (Chapter 2). As Meerim Aitkulova indicates, however, the movement also differs from the Tablighīs, in that it has an intensely political nature. Indeed, its political goal is the reestablishment of the Islamic Caliphate system and the achievement of a wholly Muslim world. Notably, though, the movement is depicted as a peaceful one that denounces the use of violence as a means for achieving its goals. Despite this, Hizb utTahrir is banned in many countries around the world, perhaps because of its political involvement. Aitkulova also examines the view expounded by a number of counter-terrorism experts that the movement can act as a first step on the ladder toward violent extremism.

In Chapter 18, "Ungoverned or Alternatively Governed Spaces in NorthEastern Nigeria: A Critical Exploration of Boko Haram's Ideological Motif," Benson Igboin discusses sub-state organizations, such as Nigeria's Boko Haram, which move in to assume leadership of so-called "ungoverned spaces" that lack strong government. Igboin takes to task Nigerian President Muhammadu Buhari, critiquing his inaugural speech delivered on 29 May, 2015, in which he promised to wipe out Boko Haram and commission a sociological study to 
examine its origins and causes. Igboin argues that President Buhari's approach runs contrary to logic, stressing that a study of the causes of violence is needed before the movement can be eradicated. The thrust of the chapter is that some of the reasons behind Boko Haram's violent tendencies are religious in nature and that, instead of killing all the movement's members, the Nigerian Government should focus on using a narrative-based deradicalization strategy to win the war of ideas.

Chapter 19 by Steven Childs is an exposition of the Lebanese Shīa political movement, Hezbollah. The assertion of Shīa identity has perennial importance within Islam, where Sunnīs are in the majority. This identity was mobilized in Lebanon during the 197os by the Lebanese-Iranian philosopher Musa al-Sadr (b. 1928, disappeared 1978), who acquired a following among the working class. Hezbollah came into existence in 1985 , with three aims: to destroy Israel; to end Israel's presence in South Lebanon; and to establish an Islamic regime in Lebanon (Childs 2011). Hezbollah's eclipsing of the secular Amal party indicated support for the Islamist position that religion and government should be united. Childs also discusses the combat style and militarization of Hezbollah and its implications for the region.

In Chapter 20, Kaarina Aitamurto examines the construction of the concept of the "sect" by the Russian media, looking specifically at the depiction of the Muslim "sect" (Baran 2006). She argues that, "in contemporary Russia, the word 'sect' has even more negative connotations than it does in Western Europe or North America." In this context, sects are often contrasted with traditional Russian Islam, which, in Soviet times, was under the control of the Orenburg Muslim Spiritual Assembly. Movements such as Wahhābism, Hizb ut-Tahrir, Nurdzhular, the National Organization of Russian Muslims (NORM), and Faizrakhmanisty, which are seen either as non-traditional or as having originated outside Russia, are labeled sects by the Russia-centric press (Aitamurto 2018). This label, Aitamurto suggests, has real consequences for these movements, in terms of societal opinion turning against them and legislative measures being adopted to hinder their activity, as the rubric of 'security' comes to dominate what were previously regarded as religious phenomena and issues.

The first part of Emin Poljarevic's contribution (Chapter 21) traverses the same ground as Chapter 14, discussing the roots of takfirism in Islam, starting with the Khawārij. He explains the similarities between the positions held by the Khawārij and Isıs that (as Wagemakers described) allow non-Jihādis to accuse ISIs of being like Khawārij. Poljarevic also provides far greater detail concerning the development of the Jihādi Salafi doctrine of takfir and subtle variations of the belief held by various Jihādist Salafis such as 'Azzām, 
al-Maqdisī, bin Lādin, Al- Zawāhirī, and Al-Zarqawi. He describes the sociocultural and political developments that led to the development of IsIs including the formation of al-Q⿱āiida in Iraq and its metamorphosis into ISIS under Al-Zarqawi's leadership.

The fourth part of the Handbook of Islamic Sects and Movements concerns Șüfism and its offshoots. Chapter 22, Marta Dominguez Diaz's "Șūfism," is a historical sketch tracing Ṣūfism's emergence and routinization into established orders, and which culminates in a discuss of contemporary transnational Șüfism. Diaz discusses whether Șūfism belongs in the Islamic mainstream or at its periphery - or even completely outside of traditional Islam. She argues that for much of Islamic history, Șüfism was, indeed, part of the mainstream (Knysh 2010). This is despite the fact that modern reformist movements such as Wahhābism insist that many (if not most) Șūfi elements are bid'a ('innovations') imported from other religions (Weismann 2011; Ridgeon 2015). Dominguez Diaz contends that much of the original criticism of extravagant Șūfi practices came from other Șūfis themselves, who were not against Șüfism per se but, rather, sought to reform Șūfism and curb what they saw as its excesses.

Chapter 23 by Milad Milani is a study of the charismatic leader Javād Nūrbakhsh (1926-2008) and the Ni'matullāhī 'Khaniqahi' Order which held from 1956 to his death. Milani notes that the Ni'matullāhì Order was established in the fourteenth century (Algar 2012) and "is by far the most widespread and significant Șūfi Order in Iran, since the time of its inception in the fourteenth century." The Order took on more sectarian lineaments when Nūrbakhsh established Khaniqahi "Houses of Șüfism" in the West in the years prior to the Islamic Revolution of 1979, the year in which he himself relocated to the United States. The type of Şufism developed in the West by Nürbakhsh, Milani avers, was significantly distanced from Islam, though in a less radical and overt way to that of Hazrat Inayat Khan (founder of Universal Șūfism) and Meher Baba (Milani 2012: 670). Thus, Ni'matullāhī Șūfism is not Islamic mysticism but rather a mystical system with historical links to Persian culture.

The next contribution to the volume is Antoon Geels' study of the Indonesian new religion, Subud (Chapter 24). Geels looks at the life and beliefs of Muhammad Subuh Sumohadiwidjojo (1901-1987), the founder of Subud, a mystical movement that, like so many of the other faith traditions examined in this book, inhabits the border region between Islam and other religions (Geels 1997). In the case of Subud, these include Șüfism, Javanese religions, and Hinduism. After identifying the key tenets of the Subud faith through a thorough examination of the original sources, Geels concludes that Sumohadiwidjojo's ideas are similar to the "general consensus" about Islam 
put forth by Șūfi Muslim scholars, even if they appear to be framed in terms of Javanese spirituality.

Chapter 25 by W. Rory Dickson considers a type of Șūfism that has moved even further from 'official' Islamic Șūism, the Traditionalist Șūfism of René Guénon (1886-1951) and his followers. Dickson sketches Guénon's interactions with various esoteric movements, and how his spiritual quest was transformed by his 1930 move to Cairo and 1934 marriage to Fatima Muhammad Ibrahim, with whom he had four children. Guénon lived an observant Muslim life but did not personally regard himself as a convert, as he believed that all Traditional religions were equally valid; "the essential unity of all traditions" rendered the possibility of conversion "meaningless and truly inconceivable" (Guénon 2004 [1952]: 63). Frithjof Schuon (1907-1998) established braches of the 'Alawiyya Order in the West, which many Traditionalists joined. Schuon's Sunfism was reformed in its ritual practices, and was informed by Vedanta, indigenous traditions and Catholicism. By the 1980s, the 'Alawiyya Order had become the Maryamiyya, after the Virgin Mary (Fitzgerald 2010: 119).

Chapter 26 is an examination of the claim that the teaching lineage of George Ivanovich Gurdieff (c. 1866-1949) called the 'Work' or the 'Fourth Way' has its origins in Central Asian Șūfism. Carole M. Cusack considers the contribution of Gurdjieff's pupil John Godolphin Bennett (1897-1974) who zealously pursued this interpretation of his teacher's ideas and practices, travelling extensively in the Islamic world to seek "out the sources of Gurdjieff's teachings from the Muslims that he met" (Pittman 2012: 123). Cusack concludes that the identification of Gurdjieff and his teachings as 'Ṣūf' is erroneous, and the Work should not be regarded as an Islam-derived esoteric system. Rather, Gurdjieff's personal creativity, eclectic borrowing from a range of traditions, and Orthodox Christian upbringing are viewed as (probably) more important in the development of the Fourth Way.

The fifth part of this volume groups together two different types of movements. These are groups that have members who believe themselves to be Muslims, despite the fact that 'mainstream' Muslims would deny them that status, and entirely separate religions that have co-existed with Islam over the centuries and have to some extent moulded their self-image and their public presence in response to this. Chapter 27 sees Muhammad Afzal Upal trace the origins of the Ahmadiyya Muslim Jamāat, which was founded in 1889 in Northwest India by Mirzā Ghulām Aḥmad (1839-1908). Aḥmad's enigmatic beliefs have puzzled scholars of religion, who have explored the various influences upon Aḥmad's thoughts, from Șūfi Islam to the reformist Ahl-e-Hadìth. In this chapter, Upal discusses the influences of rationalist South-Asian Muslim thinkers, such as Sir Syed Ahmad Khan (Robinson 1988), upon the movement 
under scrutiny. Ahmadiyya members are persecuted in various Islamic countries, in particular Pakistan, where the movement was based until the administration moved to London in 1984.

The next chapter is the first of three concerning African-American movements of which members regard themselves as Muslims. Edward E. Curtis IV covers the founding of the Nation of Islam (NOI) by W.D. Fard Muhammad in 1930 in Detroit (Chapter 28). Curtis credits Fard's successor, Elijah Muhammad, with introducing NOI's distinctive doctrine, including the notions that "Fard was God in the flesh," Elijah was the "messenger of God," and a "Mother Ship" (UFO) would play a role in Armageddon. These claims are unacceptable in the context of the Sunnī and Shī'a traditions (Curtis 2006:10-14). He also describes an attempt by Elijah's son and successor, Wallace Muhammad, to move the NOI flock closer to mainstream Islam by de-emphasizing these features. However, as noted in M. Afzal Upal's (2017) cognitive science of new religious movements, these rollbacks have provided an opening for Louis Farrakhan (Wallace Muhammad's competitor for NOI leadership) to capitalize on the very distinctive features that Wallace sought to downplay, causing a split within the NOI. Thus, as Curtis shows, Wallace Muhammad's faction has moved closer to mainstream Sunnī Islam, while Farrakhan's version of the Nor has maintained its more fringe qualities.

In Chapter 29, Fathie Ali Abdat examines the origins and history of the Moorish Science Temple of America (AMSTA), starting from its foundation in Chicago by the prophet Noble Drew Ali (1886-1929) on November 29, 1926 and moving forward to present times (Bowen 2017). He finds similar trends to those observed in relation to the Nation of Islam, with distinctive features typically not found in Sunnī Islam being prominent (such as the concept of divine status for leaders like Allah El). These, Abdat explains, have been emphasized more or less at different times in the group's history, leading to the splintering of the group into multiple branches. As the chapter demonstrates, the group has had to negotiate the fine balance between being critical of the United States government (in order to connect with the Black community) and not being seen as seditious (McGee-Bey 1968:4) in an effort to avoid legal issues). Unlike NOI, AMSTA has shied away, in the main, from the US Civil Rights struggle (and, in recent decades, has become associated with the idea of "Moorish sovereignty," which, as Abdat notes, has led to the issuing of licenses and other documents to members which make spurious claims to exempt holders from taxation and to confer other benefits.

Chapter 30 is Susan J. Palmer's "The Ansaaru Allah Community," an analysis of the group also known as the United Nuwaubian Nation of Moors among other names, founded by Dwight D. York (b. 1945), known as Dr Malachi Z. York, 
in 1967. Palmer focuses on the many transformations York's sect has undergone, and the influences that York drew upon in articulating its eclectic doctrines. In addition to Islam, York was inspired by the ancient civilizations of Sumeria and Egypt, and espoused the "ancient astronaut" theory of Zecharia Sitchin (Sitchin 1976). With regard to Islam, York has also alleged that he was initiated into the Order of Al Khidr, and also into a Șūfi Order of Khalwatiyya (Gardell 1996: 226), and between 1973 and 1992 claimed to be the Mahdi. In 2004, York was convicted of racketeering and criminal sexual activity, and received a sentence with a release date of 2120 .

In Chapter 31, Hussam Timani on the Druze begins with the efforts made by Ismāîli missionaries in the eleventh century preaching of a fresh call to monotheism or Unitarianism (al-da'wa al-tawhidiyya) (Halabi 2015: 16). Timani concludes with the recent death of the Druze sage Shaykh Abu Hasan Arif in 2004. After reviewing various theories about the ethnic origins of the Druze (relating them, for example, to French, Persian, and Jewish histories), Timani suggests that they are, in fact, an Arabic group. He also dissects the specific beliefs of the Druze, including the prominence of reincarnation, the use of wisdom books, and the importance of ta'arruf ("erudition"), which are all elements that set the Druze apart from mainstream Shīa and Sunnī Islam (Firro 1992). Finally, he argues that, while the Druze are different from the aforementioned groups, many members do consider themselves Muslims.

Victoria Arakelova's study of the history and beliefs of the Yezidi community of the Middle East concentrates in particular on persecution of the group (Chapter 32). Named after Yazid bin Ummaya, a 'villain' in Shīa history who is often held responsible for the killing of Imām Hussain, the group is known for its deification of the traditional Islamic angel of death (Arakelova 2011: 35-36). It is perhaps little wonder, then, that Yezidis are labeled 'devil worshippers' by their Sunnī and Shī'a neighbors. As Arakelova delineates, members are also known to pray to a pantheon of lesser beings, such as Sheikh Shams (the 'Lord of the Sun'), and are accused by mainstream Muslims, therefore, of engaging in shirk ('polytheism'). Arakelova also covers the persecution of Yezidis by various governments and groups, the most recent example being by ISIS (Asatrian and Arakelova 2014).

In Chapter 33 Lil Osborn considers the origins and belief system of the Bahầi community, beginning with its roots in the millennialism of nineteenthcentury Shīa Islam. Similar to the Ahmadiyyas, the Bahā'îs believe in a prophet who came after Muhammad and are thus regarded as non-Muslims by most Sunnīs and Shīas (Warburg 2003). Interestingly, though, unlike the Ahmadiyyas, the Bahāiss do not claim to be Muslims. This positionality does not enable them, however, to escape persecution in Muslim-majority countries, 
where, as Osborn discusses, they are discriminated against in private workplaces, at educational institutions, and in governmental offices (Cooper 1985).

For convenience and consistency, we have aimed to systematise the spelling and formulation of non-English words, particularly Arabic, throughout the chapters. Where and when appropriate, we have deferred to Brill's highly regarded third edition of the Encyclopaedia of Islam (EI3), edited by Kate Fleet, Gudrun Krämer, Denis Matringe, John Nawas, and Everett Rowson and released progressively online from 2007, for the translation of Arabic to romanised English. However, as this volume brings together discussions of examples and case studies that range time periods, geographic regions, and cultural as well as linguistic groups, and utilises a range of primary as well as scholarly sources, there are some natural deviations in the spelling of some names and terms notably in the chapters that reprint earlier works.

\section{Conclusion}

The recent history of violence on the part of Islamic organisations and violence experienced by Muslims across the globe is another powerful driver for this volume. On 3 August 2014 Islamic State militants attacked the Kurdish area of Northern Iraq around Mount Sinjar and killed a number of its inhabitants as it had done elsewhere in Iraq (Chulov 2014). In a new low for Islamic State, women were kidnapped and openly sold as slaves. Responding to the horrified reaction of the rest of the world, the August edition of the Islamic State mouthpiece Dabiq included a long article justifying the practice of slavery. After summarizing a discussion among medieval scholars about whether the inhabitants of the area, who referred to themselves as Yezidis, are better classified as mushrikeen (idolators), murtaddin (apostates) or ahl al-Kitāb (people of the Book), it concluded with a fatwa by Is's pre-eminent scholars that Yezidis were idolators. Thus, the enslavement and concubinage of Yezidi women was not only allowed, but required, according to Islamic tradition:

One should remember that enslaving the families of the (non-believers) and taking their women as concubines is a firmly established aspect of the Shariah, that if one were to deny or mock, he would be denying or mocking the verses of the Quran and the narrations of the Prophet.

Dabiq 2014 
This set up a flurry of activity among the Western decision makers and Middle East analysts to find any scholars or published material that could explain to them who Yezidis were and what their connections to Islam was. This search was not made easier by the fact that most modern scholarship on Islam limits itself to studying orthodox Sunnī and Shī'a traditions at the expense of heterodox Islamic movements and religious traditions that originated in the Islamic world and the connections that these movements have with Islam. In the same year Garnik S. Asatrian and Victoria Arakelova published The Religion of the Peacock Angel: The Yezidis and Their Spirit World, one of the first academic monographs on Yezidism and an important milestone in documenting this small, vulnerable community (Asatrian and Arakelova 2014). To understand Islamic State's actions in August 2014, we needed to understand Yezidis and their connections their faith has with Islam. To understand the blockade of Pakistani capital Islamabad by Sunnī Tehrik-e-Labaik ya Rasoolullah in first three weeks of November 2017 and the subsequent capitulation of the Pakistani state to the protesters one needs to understand the relationship between Ahmadiyya Muslim Jamā'at and its origin in Sunnī Islam (Daily Dawn 2017). To understand the attacks on Yemeni Bahâ̄is that took place following the capture of Sanaa by Houthi rebels in 2014, one needs to understand the relationship between Shī'ite Islam and Bahāīsm (The National 2018). If scholars want to better understand Islam as well as religious movements originating in Islam (whether considered part of Islam by Muslims or not), they cannot afford to continue the current practice of artificially separating the two. Scholars of Islam need to pay more attention to religious movements that originated in Islam and scholars of these movements need to know more about Islam. Scholarships of both will improve from a continuous dialogue between them. Thus, we hope that the dialogue that this this book has initiated between scholars of Islam and scholars of religious movements originating in Islam not only continues but flourishes, enriching us all.

\section{References}

Aitamurto, K. 2018. "The Faizrakhmanisty: The Islamic Sect as a Social Problem in Russia." Alternative Spirituality and Religion Review. 9:2, 165-189.

Algar, H. and J. Burton-Page. 2012. "Ni'mat-Allahiyya." In P. Bearman, Th. Bianquis, C.E. Bosworth, E. van Donzel and W.P. Heinrichs, eds, Encyclopaedia of Islam, Second Edition. At https://referenceworks.brillonline.com/browse/encyclopaedia -of-islam-2. Accessed o6/o5/2019. 
Arakelova, V. 2011. "On Some Derogatory Descriptions of Esoteric Religious Groups." In M. Szuppe, A. Krasnowolska, and C.V. Pedersen, eds, Mediaeval and Modern Iranian Studies. Paris: Association pour l'Avancement des Études Iraniennes, 33-44. Asatrian, G. and V. Arakelova. 2014. The Religion of the Peacock Angel: The Yezidis and their Spirit World. Durham: Acumen.

Baran, E.B. 2006. "Negotiating the Limits of Religious Pluralism in Post-Soviet Russia: The Anticult Movement in the Russian Orthodox Church, 1990-2004." Russian Review. 65:4, 637-656.

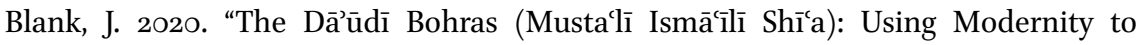
Institutionalise a Fātimid Tradition." Chapter 11 in this volume.

Bowen, P.D. 2017. A History of Conversion to Islam in the United States, Volume 2. Leiden and Boston: Brill.

Childs, S. 2011. "From Identity to Militancy: The Shīa of Hezbollah." Comparative Strategy. 30:4, 363-372.

Chulov, M. 2014. "40,00o Iraqis stranded on mountain as Isis jihadists threaten death." The Guardian, 7 August. At: https://www.theguardian.com/world/2014/aug/ o7/400oo-iraqis-stranded-mountain-isis-death-threat, accessed 1 August 2020.

Cooper, R. 1985. The Bahä'̄̌s of Iran: The Minority Rights Group Report 51. London: The Group.

Curtis, E.E. IV. 2006. Black Muslim Religion in the Nation of Islam, 1960-1975. Chapel Hill, NC: University of North Carolina Press.

Dabiq. 2014. Issue 4 as quoted in Newsweek, 13 October. At http://www.newsweek.com/ islamic-state-seeks-justify-enslaving-yazidi-women-and-girls-iraq-27710o retrieved on May 23. Accessed o1/o8/2018.

Daftary, F. 2020. "The Ismailis and Their Traditions." Chapter 10 in this volume.

Daily Dawn (Pakistan). 2017. "How the Islamabad protests happened." 25 November. At https://www.dawn.com/news/137280o. Accessed 23/o5/2018.

Dressler, M. 2013. Writing Religion: The Making of Turkish Alevi Islam. Oxford: Oxford University Press.

Faksh, M.A. 1984. "The Alawi Community of Syria: A New Dominant Political Force." Middle Eastern Studies. 20:1, 133-153.

Fazlhashemi, M. 2020. "Imamiyya. Shi'a (The Twelvers)." Chapter 8 in this volume.

Firro, K.M. 1992. A History of the Druze. Leiden: E.J. Brill.

Fitzgerald, O. 2010. Frithjof Schuon:Messenger of the PerennialPhilosophy. Bloomington: World Wisdom.

Gardell, M. 1996. In the Name of Elijah Muhammad: Louis Farrakhan and the Nation of Islam. Durham: Duke University Press.

Geels, A. 1997. Subud and the Javanese Mystical Tradition. Richmond, UK: Curzon Press.

Guénon, R. 2004 [1952]. Initiation and Spiritual Realization. Hillsdale, NY: Sophia Perennis. 
Haider, N. 2014. Shi' Islam: An Introduction. Cambridge: Cambridge University Press. Haider, N. 2020. "Zaydism in the Balance Between Sunnī and Shī‘a." Chapter 9 in this volume.

Halabi, A. 2015. The Druze: A New Cultural and Historical Appreciation. Reading, UK: Ithaca Press.

Hoyland, R.G. 2000. "The Earliest Christian Writings on Muhammad: An Appraisal." In H. Motzki, ed., Muhammad: The Issue of the Sources. Leiden and Boston: Brill, 276-297.

Husain, E. 2018. The House of Islam: A Global History. London and New York: Bloomsbury. Knysh, A.D. 2010. Islamic Mysticism: A Short History. Leiden: Brill.

Lav, D. 2012. Radical Islam and the Revival of Medieval Theology. Cambridge: Cambridge University Press.

Makin, Al. 2010. Representing the Enemy: Musaylima in Muslim Literature. European University Studies, New York: Peter Lang.

McGee-Bey, J. 1968. "Letters to the Editor." Chicago Defender. 10 June.

McLeod, W.H. 1968. "The Influence of Islam on the Thought of Guru Nanak." History of Religions. 7:4, 302-316.

Milani, M. 2012. "The Cultural Products of Global Șūfism." In C.M. Cusack and A. Norman, eds., Handbook of New Religions and Cultural Production. Leiden and Boston: Brill, 659-68o.

Neitz, M.J. 2011. "Lived Religion: Signposts of Where we have been and Where we can go from Here." In G. Giordan and W.H. Swatos Jr, eds, Religion, Spirituality and Everyday Practice. Cham, Switzerland: Springer, 45-55.

Nesbitt, E. 2005. Sikhism: A Very Short Introduction. Oxford: Oxford University Press.

Nisa, E. 2020. "Women and Islamic Movements." Chapter 7 in this volume.

Pieri, Z. 202O. "Tablīghī Jamā'at." Chapter 2 in this volume.

Pittman, M.S. 2012. Classical Spirituality in Contemporary America: The Confluence and Contribution of G.I. Gurdjieff and Șūfism. London and New York: Continuum.

Poljarevic, E. 2019. "Theology of Violence-oriented Takfirism as a Political Theory: The Case of the Islamic State in Iraq and Syria (ISIS)." Chapter 21 in this volume.

Ridgeon, L. ed. 2015. Șūfis and Salafis in the Contemporary Age. London: Bloomsbury Publishing.

Robinson, F. 1988. Varieties of South Asian Islam. Warwick, UK: Centre for Research in Ethnic Relations, Research Paper Number 8, University of Warwick.

Sedgwick, M. 2000. "Sects in the Islamic World." Nova Religio: The Journal of Alternative and Emergent Religions. 3:2, 195-240.

Singh, P. 2014. "The Guru Granth Sahib." In The Oxford Handbook of Sikh Studies, ed. P. Singh and L.E. Fenech, 125-135. Oxford: Oxford University Press.

Sitchin, Z. 1976. The 12th Planet. New York: Stein and Day. 
Swatos, W.H. (Jr). 2007. Sect. In G. Ritzer, ed., The Blackwell Encyclopedia of Sociology. Oxford: Blackwell, 4135-4140.

Talhamy, Y. 2020. "The Alevīs and 'Alawīs." Chapter 12 in this volume.

The National (Abu Dhabi). 2018. "Houthis ramp up war against Yemen's Bahā'ì Minority." 27 March. At https://www.thenational.ae/world/mena/houthis-ramp-up -war-against-yemen-s-baha-i-minority-1.716444. Accessed 23/o5/2018.

Thurfjell, D. 2020. "The Hey'Ati Movement: Charismatic Preachers, Politics and Youth Culture." Chapter 13 in this volume.

Timani, H. 2017. Takfir in Islamic Thought. New York, NY: Lexington Books.

Upal, M.A. 2017. Moderate Fundamentalists: The Ahmadiyya Muslim Jamā'at in the Lens of Cognitive Science of Religion. Berlin: De Gruyter.

Van Ess, J. 2001. "Political Ideas in Early Islamic Thought." British Journal of Middle Eastern Studies. 28:2, 151-164.

Wagemakers, J. 2012. A Quietist Jihadi: The Ideology and Influence of Abu Muhammad al-Maqdisi. Cambridge: Cambridge University Press.

Wagemakers, J. 2020. "The Citadel of Salafism." Chapter 14 in this volume.

Wajihuddin, M. 2017. "Deoband campus now off limits for Tablighi Jamaat." The Times of India, 11 August. At https://timesofindia.indiatimes.com/india/deoband -campus-now-off-limits-for-Tablighi-jamaat/articleshow/6oo12605.cms. Accessed o1/08/2018.

Warburg, M. 2003. Bahā’̀̄. Salt Lake City, UT: Signature Books.

Weismann, I. 2011. "Modernity from Within: Islamic Fundamentalism and Șūfism." Der Islam. 86:1, 142-170.

Willis, M. 2012. Politics and Power in the Maghreb: Algeria, Tunisia and Morocco from Independence to the Arab Spring. New York: Columbia University Press. 